\title{
Fiscal Imbalances and Borrowing Costs: \\ Evidence from State Investment Losses
}

\section{By Robert Novy-Marx and Joshua D. Rauh \\ Web Appendix}

\section{Technical Appendix 1: The Black Value of a Swaption}

A swaption is an option to take a position in an interest-rate swap agreement at some date in the future, where the swap's fixed rate is specified in the swaption contract. The state can force bond holders to deliver their fixed coupon bonds in exchange for a lump-sum payment, usually par. Because a bond newly issued at the swap rate trades at par, this is equivalent to forcing the bond holders to exchange a stream of fixed payments (the bond's coupons) for a different, currently unknown, stream of fixed payments (the future swap rate). Options of this sort are typically valued using Black’s model for options on futures (see Technical Appendix 1 for details). The implicit assumption is that the future swap rate is log-normally distributed around its current level. Bloomberg provides swaption prices, quoted in Black volatilities (i.e., the implied volatility of the future swap rate), for expiration dates out to ten years written on swaps with up to ten years maturity at option expiration. The implied volatility surface interpolated from this matrix can be used, with Black's model, to calculate the value of a swaption with any time to expiration and tenor. Our prices are for swaptions written on US dollar LIBOR, and we consequently have the volatility surface for LIBOR swap rates. We employ it here as the best available proxy for the volatility surface for muni swap rates.

For each callable bond, we calculate its option-free price by summing 1) the bond's price obtained from Bloomberg, and 2) the price of the receiver swaption struck at the bond's coupon 
rate, expiring on the bond's first call date, with a tenor equal to the call's remaining maturity at expiry. We then add back accrued interest, which is not included in the quoted prices. Under market conventions, quoted prices do not include any interest that has accrued since the last coupon date, which the bond purchaser is required to buy at the time of purchase.

Here we show the computation of the Black value of a swaption, expiring in $t$ and written on a swap with tenor $T$ making semi-annual payments at the rate $c$. Define $\mathrm{F}$ as the future swap rate, adjusted for the call's strike:

$$
F=\frac{2\left((\text { strike } / \text { face }) \times B_{t}-B_{t+T}\right)}{\sum_{i=1}^{2 T} B_{t+i / 2}}
$$

where $B_{\tau}$ in the price of a zero-coupon bond of the same quality as the bond underlying the swap maturing at $\tau$. The Black value of the swaption is then

$$
A \times\left(\frac{c}{2} N\left(-d_{2}\right)-\frac{F}{2} N\left(-d_{1}\right)\right)
$$

where $A$ is the sum of the state prices for all the swap's payment dates, $N$ is the cumulative normal distribution $\sigma$ is the implied volatility of a swap maturing it $t$ with tenor $T, d_{1}=$ $\frac{\log (F / c)+\sigma^{2} t / 2}{\sigma \sqrt{t}}$, and $d_{2}=d_{1}-\sigma \sqrt{t}$. 


\section{Technical Appendix 2: Capital Gains Taxes and the Risk-Neutral Hazard Rate of Default}

This appendix shows how the capital gains tax rate affects the relationship between the measured increase in spreads and the increase in the risk-neutral hazard rate of default. The after tax expected instantaneous risk-neutral yield on the bond should equal that on a risk-free (taxable) asset. That is $\left(y-\left(1-\tau_{c . g .}\right) \alpha \lambda^{*}\right) d t=\left(1-\tau_{e . i .}\right) r_{f} d t$

where $y$ is the yield on the muni bond, $\alpha$ is the loss in the event of default, $\tau_{c . g .}$ and $\tau_{e . i .}$ are the tax rates on capital gains and earned interest, respectively, and $\lambda^{*}$ is the risk-neutral hazard rate of default. The change in the risk-neutral hazard rate of default is related to the change in yield by $\Delta \lambda^{*}=\frac{\Delta y}{\left(1-\tau_{c . g .}\right) \alpha}$. 


\section{Appendix Table 1: Asset Allocation and Asset Class Returns}

The top panel shows asset allocation for 71 investment funds across 116 pension plans for 50 states as reported by Pensions and Investments, as of September 2008. As a proxy for the returns to domestic stock, international stock and real estate we use the returns to Barra/MSCI Investible Indices (USA, World ex-USA and US REIT, respectively). For domestic fixed income, international fixed income, mortgages and the "other" category we use Barclays Capital Indices (US Government/Credit, Global Aggregate Ex USA, US MBS and Asset-Weighted Hedge Fund, respectively). The returns to cash and equivalents are from Ken French's website (one month risk-free rate). For the return to private equity we use the mid-point of the range estimated by Steven N. Kaplan (private conversation).

Asset-Weighted Average Asset Allocation

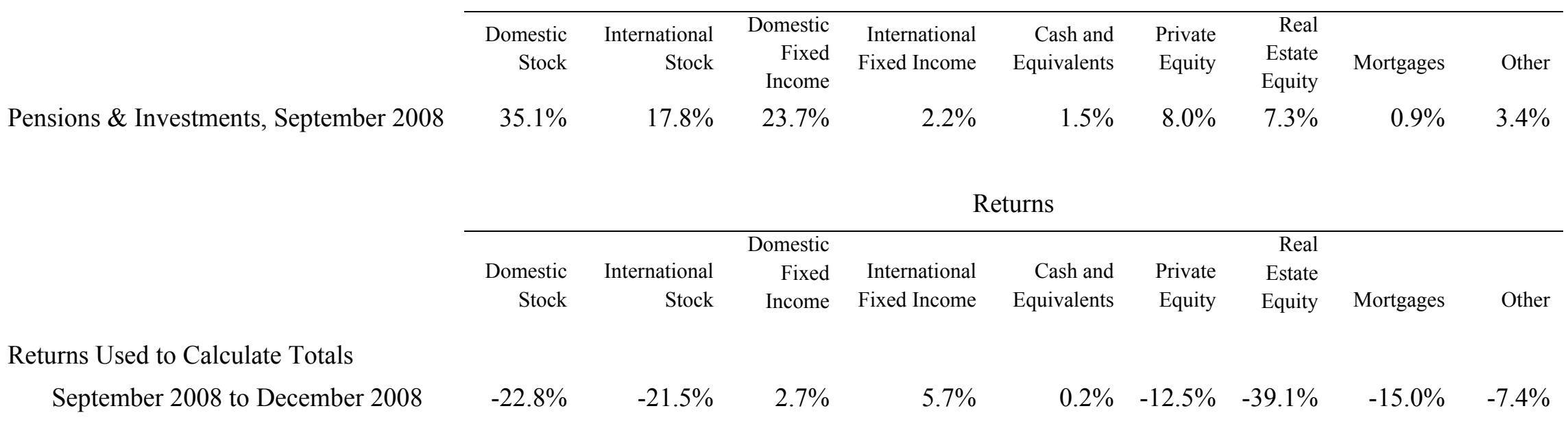




\section{Appendix Table 2: Falsification Exercise Using Pre-Refunded Bonds}

This table is a version of Table 3 that uses the pre-refunded bonds only, as opposed to the not pre-refunded bonds, as a falsification exercise.

\begin{tabular}{|c|c|c|c|}
\hline \multirow[b]{2}{*}{ [Rated AA or Below $]^{*}[$ Loss/Revenue $]$} & \multicolumn{3}{|c|}{ Dependent Variable: Change in Yield Spread } \\
\hline & $\begin{array}{l}-0.18 \\
(0.14)\end{array}$ & $\begin{array}{l}-0.26 \\
(0.12)^{* *}\end{array}$ & $\begin{array}{c}0.19 \\
(0.30)\end{array}$ \\
\hline [Loss/Revenue] & $\begin{array}{c}0.01 \\
(0.12)\end{array}$ & $\begin{array}{l}-0.02 \\
(0.12)\end{array}$ & $\begin{array}{l}-0.30 \\
(0.38)\end{array}$ \\
\hline [Rated AA or Below] & $\begin{array}{c}0.03 \\
(0.07)\end{array}$ & $\begin{array}{c}0.10 \\
(0.06)\end{array}$ & $\begin{array}{l}-0.08 \\
(0.13)\end{array}$ \\
\hline Insured & $\begin{array}{c}0.04 \\
(0.02)^{* *}\end{array}$ & $\begin{array}{c}0.03 \\
(0.02)^{* *}\end{array}$ & $\begin{array}{c}0.13 \\
(0.03)^{* * *}\end{array}$ \\
\hline Duration & $\begin{array}{l}0.17 \\
(0.02)^{* * *}\end{array}$ & $\begin{array}{l}0.15 \\
(0.02)^{* * *}\end{array}$ & $\begin{array}{l}0.21 \\
(0.02)^{* * *}\end{array}$ \\
\hline Convexity $\div 100$ & $\begin{array}{c}0.07 \\
(0.18)\end{array}$ & $\begin{array}{l}0.23 \\
(0.08)^{* * *}\end{array}$ & $\begin{array}{l}-0.04 \\
(0.06)\end{array}$ \\
\hline Size of Issue (B) & $\begin{array}{c}0.03 \\
(0.02)\end{array}$ & $\begin{array}{c}0.03 \\
(0.02)\end{array}$ & $\begin{array}{l}-0.14 \\
(0.06)^{* *}\end{array}$ \\
\hline State Debt / Revenues & $\begin{array}{l}-0.07 \\
(0.02)^{* * *}\end{array}$ & $\begin{array}{l}-0.10 \\
(0.02)^{* * *}\end{array}$ & $\begin{array}{l}-0.03 \\
(0.03)\end{array}$ \\
\hline Pension Liabilities / Revenues & $\begin{array}{l}-0.00 \\
(0.01)\end{array}$ & $\begin{array}{c}0.00 \\
(0.01)\end{array}$ & $\begin{array}{c}0.02 \\
(0.03)\end{array}$ \\
\hline Sensitivity of Own Revenue to U.S. GDP Growth & $\begin{array}{l}-0.29 \\
(1.24)\end{array}$ & $\begin{array}{c}1.81 \\
(1.78)\end{array}$ & $\begin{array}{c}2.19 \\
(2.73)\end{array}$ \\
\hline Own Revenue Drop & $\begin{array}{l}-0.30 \\
(0.17)^{*}\end{array}$ & $\begin{array}{l}-0.02 \\
(0.22)\end{array}$ & $\begin{array}{l}-0.15 \\
(0.37)\end{array}$ \\
\hline Constant & $\begin{array}{l}-0.07 \\
(0.05)\end{array}$ & $\begin{array}{l}-0.08 \\
(0.05)\end{array}$ & $\begin{array}{l}-0.25 \\
(0.09)^{* * *}\end{array}$ \\
\hline$R^{2}$ & 0.76 & 0.80 & 0.80 \\
\hline Sample & Pre-Refunded & $\begin{array}{c}\text { Pre- } \\
\text { Refunded, } \\
\text { Issue }>\$ 10 \mathrm{M}\end{array}$ & Pre-Refunded \\
\hline $\begin{array}{l}\text { Weights } \\
N\end{array}$ & $\begin{array}{l}\text { None } \\
2567\end{array}$ & $\begin{array}{l}\text { None } \\
1277\end{array}$ & $\begin{array}{l}\text { Issue Size } \\
2567\end{array}$ \\
\hline
\end{tabular}

Robust standard errors in parentheses, clustered by state

$*$ significant at $10 \%$; $*$ significant at $5 \%$; $* *$ significant at $1 \%$ 